\title{
Free Senior High School (SHS) and Quality University Education in Ghana: The Role of the University Teacher
}

\author{
Samuel Adu-Gyamfi ${ }^{1}$ \\ Charles Ofosu Marfo ${ }^{2}$ \\ Ali Yakubu Nyaaba ${ }^{1}$ \\ Kwasi Amakye-Boateng ${ }^{1}$ \\ Mohammed Abass ${ }^{1}$ \\ Henry Tettey Yartey \\ ${ }^{I}$ Department of History and Political Studies, \\ Kwame Nkrumah University of Science and Technology, Kumasi, Ghana \\ ${ }^{2}$ Department of Language and Communication Sciences, \\ Kwame Nkrumah University of Science and Technology, Kumasi, Ghana
}

DOI: https://doi.org/10.36941/jesr-2020-0101

\section{Abstract}

\begin{abstract}
Ghana's education system has gone through several reforms in the post-independence period in the bid to increase access, ensure equity and quality at all levels (basic to tertiary). However, these goals seem to be a mirage especially on issues concerning quality at the secondary and tertiary levels. Against this backdrop, it has become imperative to raise relevant questions for the development of a new synthesis that is practical enough to allow for the necessary action to push forward the quality discourse which is a major concern among stakeholders. This paper intends to at least, serve the purpose of refreshing our memories concerning how we have individually or collectively, as citizens and academics, pondered over free secondary education, quality education and the role of the university teacher within the melting pot of the quality discourse in Ghana. It also serves the purpose of instigating a discourse on teachers' role in ensuring quality education.
\end{abstract}

Keywords: Education, Quality, University, Teacher's Role, Ghana

\section{Introduction}

On $15^{\text {th }}$ September, 2017 at exactly o1:40pm, VOA Africa reported "Ghana Launches Free High School Education". The VOA, Francisca Kakra Forson presented; "Education at the secondary high school level is now free in Ghana. President Nana Akufo Addo announced the launch of the programme Tuesday, calling it a necessary investment in the nation's future work force. The response was enthusiastic, with parents and students forming long queues at public schools around Accra this week to register before classes open September 18" (Forson, 2017).

Prior to the so-called momentous declaration by his Excellency, the President of the Republic, 
Ghana's educational sector especially the Basic, Junior High and Senior High School had witnessed or seen several conspicuous reforms which were aimed at growing education especially during the postcolonial period up to the turn of the new millennium. Some of these reforms included the 1960 Feefree Compulsory Primary and Middle School Education, the Education Act of 1961 and the Free Compulsory Universal Basic Education (FCUBE) among others (Adu-Gyamfi et al., 2016). Adu-Gyamfi et al. (2016) argued, among other things, that the various reforms that characterized Ghana's education system in terms of implementation can generally be categorized into two major kinds: "Reforms that cut across the length and breadth of the country and radical reforms where the government might want to play — some politics - with reform."

In problematizing this discourse, it is essential to establish the fact that some exclusive studies have been done on Senior High School education and free SHS in particular. Again, some studies have been done on quality university education and the role of lecturers among others. There are also studies that focus on the nature of the relationship between academia and government among others. Some of these studies include the works of Green (1971), Friesen and Boberg (1990), Barrett et al. (2006), Morley et al. (2009), Asiyai (2013; 2015), Hameed (2017) and Abdul-Rahaman et al. (2018) that draw our attention to pertinent issues concerning education, the role of teachers and free education among others. Other studies covering Senior High School education in Ghana such as Bibby and Peil (1974), Lloyd and Gage-Brandon (1992), Acheampong (2010) and Hameed (2017) have addressed the question of enrollment, performance and how these impact on students, households and the country at large.

The above notwithstanding, the existing literature has not fully addressed the issue of free SHS and quality university education; specifically, the role lecturers play in ensuring the delivery of quality education. It has become imperative to raise relevant questions today for the development of a new synthesis that is practical enough to allow for the necessary action to push forward the quality discourse which is a major concern among stakeholders. This will enable us build the kind of system that shall produce cutting-edged graduates in the present and the foreseeable future.

Striving to achieve this, there is the need to shy away from being Utopian. University lecturers must shy away from perceived chasms and abracadabra moments. This paper highlights the thoughts and the intellectual positions penned by accomplished scholars. Therefore, this paper, among other things, intends to serve the purpose of refreshing the memories of intellectuals and policy makers concerning how academics have individually or collectively, as citizens pondered over free secondary education, quality education and the role of the university teacher within the melting pot of the quality discourse. Again, we anticipate that policy makers and stakeholders shall be able to ask themselves some relevant questions which shall support the quality discourse concerning the need to resolve challenges arising from increasing student population, limited number of lecturers and limited infrastructure among others.

For the purpose of comprehensibility, the paper is divided into the following sub-sections; the introduction, literature review, the method of the study, and the discussions which comprise of; the Concept of Free Senior High School Education in Ghana, and the Role of the University Teacher in Ensuring Quality University Education under the Free SHS in Ghana with sub-themes and Conclusion.

\section{Literature Review}

This section is a conceptual review that looks at related literature on the concept of quality in education. Significantly, materials that are in sync with the study have been reviewed. Among the materials which were reviewed are DuBrin (1997), Majasan (1998), Sall et al. (2003), Schuller et al. (2004), Chimombo (2005), Mwiria et al. (2007), Manuh et al. (2007), Asiyai (2013), Ololube et al. (2013) and Schindler et al. (2015) among others. 


\subsection{The concept of Quality in Education}

Scholars of different orientation/persuasions have not come to a consensus on the definition of quality. In the latter part of the twentieth century, DuBrin (1997) defined quality as "a desirable attribute of a product or service that distinguishes it for the person seeking the attribute." Writing in the new millennium too, Schindler et al. (2015) conceptualized the term under four main themes. These are; quality as purposeful, exceptional, transformative and accountable. For the purpose of the current discourse, borrowing from Schindler et al. (2015), the definition of quality would be used to denote the transformative process whereby services (teaching) impacts positive change on students through affective, cognitive and psychomotor domains.

The concept of quality in education varies and is dependent on the context in which one uses it (UNESCO, 2014; Schindler et al. 2015). In the Lithuanian context for instance, quality education is a means to achieve expected formal educational goals that can meet personal needs of the individual and the larger society (UNESCO, 2014). Asiyai's (2013) study also argues that quality education is primarily aimed at equipping the recipients (students) with relevant skills, knowledge, ideas, values and attitudes needed to enable the students to make well-informed decisions and live a selfsustaining life. Schuller et al. (2004) have reported among other things that on the international scene, higher education and university education in particular is consistently placed at the center to serve as a fulcrum for the facilitation of the skills, knowledge and expertise that are essential to economic and social development. An earlier research by Majasan (1998) has also opined that quality education is "expected to address critical issues like the dignity of labour, quality leadership and committed citizenship, industrial harmony, political stability, religious tolerance, self-reliance and security."

It is reported that quality in education include all the functions and activities in schools (Asiyai, 2013). In line with this, by the close of the twentieth century, the World Conference on Higher Education (1998) enumerated such functions and activities to include teaching, research and scholarship, community service, staffing, students' roles, infrastructure and educational facilities, equipment and the academic environment (World Conference of Higher Education, 1998). The Ministerial Round Table on Quality Education by UNESCO organized in 2003 reported that quality education should equip all people to be fully participating members of their own communities and to act as citizens of the world (UNESCO, 2003 in Asiyai, 2013).

\subsection{Indicators of Quality Education}

The literature show inconsistencies and variations in the concept of quality and the indicators of same in education. Significantly, there are no fixed indicators used to assess the quality of education worldwide. This notwithstanding, we can glean some golden nuggets from the literature on the subject matter. A study by Schindler and her contemporaries has put forward the argument that quality in education can be assessed with a cornucopia of indicators. They identified learner-centered approach, the competency of lecturers, clarity of outcomes, development of critical thinking and student engagement with content as major indicators of quality education (Schindler et al., 2015). Similarly, Ololube et al. (2013) have also suggested some factors that influence the quality of education. These include; "the performance of teachers, the nature of the course, the devices put in place by the institution to enhance the quality of teachers' performance, the existence of appropriate accommodation, furniture and equipment for teaching as well as good library and learning facilities" (Ololube et al, 2013). According to Chimombo (2005), quality in education transcends the mere idea of better teaching environment, more qualified teachers and the adequate provision of textbooks. Essentially, quality education should proffer solutions to the puzzling questions of society. The society thus, feels the impact of universities through quality of teaching and research, production of knowledge, contributions to national and global policies, production of goods, inventions among other things that serve as solutions to societal problems (Sall et al., 2003 in Manuh et al., 2007). 
Significantly, there has been a private interest in higher education as people now challenge the mode of quality education delivery. This is based on the fact that private entities demand quality and skilled graduates to manage their work. In Kenya, employers express their concerns about the ability of university graduates to respond flexibly and completely to the responsibilities with which they are entrusted (Mwiria et al., 2007).

\subsection{The Concept of Quality Assurance in Higher Education}

In the quest to achieve quality in our universities, we cannot overlook the issue of quality assurance. Quality assurance is believed to be "an umbrella concept for a host of activities that are designed to improve the quality of inputs, process and outputs of higher education process" (Okebukola, 2010 in Asiyai, 2013). Asiyai (2013) is of the view that one of the important keys of quality assurance is the development of minimum standards that would allow for the development of stronger operating policies and procedures which are well documented and adhered to. These minimum standards include; qualification of teachers, the quality of teaching in institutions, expected educational achievement of students and the development of a more rigorous management process for education (Asiyai, 2013).

The above elucidation from the literature notwithstanding, it is still essential to look at what constitutes quality and quality university education in the context of upward mobility of the increasing number of senior high school graduates who will be enrolling into the university level from year to year due to the free education policy. To emphasize, this will serve a purpose of enlightening stakeholders concerning the role of the university teacher in ensuring quality university education with the implementation of the free SHS policy in Ghana.

\section{Method of the Study}

The current study deploys a systematic literature review approach. Significantly, the researchers conducted a systematic search in various journals, books and databases related to education, quality education, free education and the role of the university teacher.

A thorough electronic search was done in useful educational databases such as Educational Resources Information Centre (ERIC), Educational Research Complete, ProQuest and Google scholar. Our searches in the various databases followed themes such as 'free education,' 'quality education', 'the role of the university teacher', 'the role of the teacher in education' and 'free education in Africa.' Aside electronic, manual searches were done in books and reports. Among the materials consulted include Manuh et al. (2007), Reports from the National Council for Tertiary Education (2012; 2014; 2017), Mulryan-Kyne (2010), Heck and Williams (1984) and Akyeampong (2009). Also, we examined the various bibliographical entries of the various materials for additional sources.The criteria for selecting a material was dependent on the idea that it was written in English and is concerned with the current discourse. In order to achieve the set objectives, the authors were purposive and random at selecting from the cornucopia of sources including information from Ministry of Education (MOE) and other relevant internet sources.

In presenting the reports, we synthesized the information and ideas from these sources not necessarily to paint a picture, but to allow the university teacher and stakeholders (partners) to tease out the issues and reflect on what is achievable in the quest to ensure quality with the increasing demands and expectations of stakeholders.

\section{Discussions}

The discussion section of the current discourse has been grouped under three main thematic areas. We first discussed and analyzed the concept of free education, its mode of implementation and impact thus far in Ghana. The second theme focuses on quality university education across space and 
time. Finally, the section discusses the role of the university teacher in ensuring quality university education under free SHS in Ghana. Under this section, the anticipated dilemmas of increase in enrolment vis-à-vis the already fragile university communities in the country have been addressed. The authors gleaned information from the literature to ask questions and make projections on the discourse under review.

\subsection{The Concept of Free Senior High School Education in Ghana}

With the adoption of the 1992 constitution of Ghana, the country envisaged making secondary and higher education available and accessible to all Ghanaians by every appropriate means, especially through the introduction of progressive free education (Constitution of the Republic of Ghana, 1992). Article 25(1b) states; "secondary education in its different forms, including technical and vocational education shall be made generally available and accessible to all by every appropriate means, and in particular, by the progressive introduction of free education" (Constitution of the Republic of Ghana, 1992). On the 12th day of September 2017, Ghana launched the Free Senior High School Education Policy. What does this policy entail?

If free secondary education is supposed to mean one thing as argued by Hameed (2017), then it means "the era where students dropped out from school for financial reasons, or had their education cut short has become a thing of the past" (Hameed, 2017). Abdul-Rahaman et al. (2018) have added that the policy "seeks to bridge the enrollment gap between the rich and the poor". It also aims at increasing the enrollment of students and improving quality through academic performance (AbdulRahaman et al, 2018). The rationale behind free education in Ghana is not different from what we see from other countries that have implemented same. For instance, free education in Sri Lanka aims at reducing educational costs and help students to study without facing burdens from educational related costs (Asankha, 2011). In Uganda (the first sub-Saharan African country to adopt a free secondary education policy), the policy results in an increase in student enrollment in the public secondary schools yearly (Chapman et al., 2009; Asankha and Takashi, 2011).

The major proponents and supporters of the free education, and for that matter Free Senior High School Education, have argued, generally, that the policy has necessitated an increase in enrolment (access to secondary education) as evidenced in the works of Chimombo (2005), Chapman et al. (2009), Asankha and Takashi (2011), Asankha (2011) and Hameed (2017) among many others.

In the Education Sector Analysis for 2018, the Ministry of Education (MoE) reported that; "Secondary education is a dynamic space in Ghanaian education, with many changes ongoing, not least the roll-out of the free SHS policy, with the aim of dramatically increasing access to SHS by removing cost as a potential barrier" (MoE, 2018). Significantly, the informed media in Ghana reported that approximately 400,000 students were enrolled into S.H.S. in 2017 while approximately 500,000 students were enrolled in 2018 (Myjoyonline.com, 04/o9/2017). Also, the Minister of Education reported that the percentage of students' enrolment in 2017 was $83.9 \%$ indicating an improvement of $75 \%$ from 2016 (Moe.gov.gh, 2017). These suggest a persistent increase in secondary school enrolment in the years ahead and this will enrollment at the university level. Studies like that of Chimombo (2005), Chapman et al. (2009), Asankha and Takashi (2011), Asankha (2011), Ngeno and Simatwa (2015) as well as Asumadu (2019) have addressed the issue of increasing access to education at all levels. But is access everything?

The work of Manuh et al., (2007) revealed that "the expansion in access to university education without commensurable growth in staffing, infrastructure, related facilities, access to international databases and spending on students have raised major concerns over its quality." The major proponents of free education premised their argument, among other things, on the benefits of having a highly literate society. The question is, which literate society? A fully baked literate society or a halfbaked one? Ten years ago, Morley et al. (2009) raised the need for questions to be posed concerning how higher education relates to policy discourses of poverty reduction and the Millennium Development Goals (MDGs) (Morley et al, 2009). That notwithstanding, it is instructive to argue that 
some questions must also be posed concerning the Sustainable Development Goals (SDGs).

The proponents of free SHS must continuously refresh their memories concerning the fact that, in the policy field of higher education, the concepts of access and widening participation saturate the discussions on diversity, equity and disadvantage which sometimes become a form of critique of public universities (Morley et al, 2009). Morley et al. (2009) argue that higher education has always been rationed prior to the Free Senior High School Education (FSHSE). The new criteria which subsisted and continue to subsist in the rationing process include attention to diversity and social inclusion. However, the literature on higher education acknowledges the fact that some tensions have existed between the providers of higher education and would be consumers of same. The issues include fears about quality and standards, funding and capacity challenges among others.

\subsection{The Role of the University Teacher in Ensuring Quality University Education under the Free SHS in Ghana}

University education is defined and put into practice in various ways by different groups and individuals (Bess and Webster, eds. 1999). As argued by Bess and Webster, eds. (1999), "higher education can be an essential means of upward job and social mobility, a socializing agency for middle class cultural conditioning, a training ground for work, a locus for learning how to think and express oneself, or a place for personal discovery and growth uninhibited by daily requirements for making a living or caring for a family." Manuh et al. (2007) assert that universities are fundamentally established for knowledge production and it is in pursuance of this goal that universities influence the society (Manuh et al., 2007). Lecturers are to equip students with cognitive, affective and practical skills which go a long way to usher them (students) into self-development (Bess and Webster, eds. 1999).

Wong and Chiu (2017) posit that there has been a shift in the rationale behind university education these days. They argue that majority of university students are only hunters of degrees. Thus, they are only interested in attaining the degree rather than becoming intellectuals. Students perceive university education as the reproduction of assimilated lecture materials for the purpose of passing examination (Mwiria et al., 2007). This has influenced the way lecturers teach, in that they design their courses to prepare students as pragmatic individuals rather than as future scholars. In their article, "The Knowledge Economy, the Techno-Preneur and the Problematic Future of the University", Kenway and her contemporaries (2004) argued among other things that "it is inevitable that changing the relationship that frame knowledge production will change the nature of the knowledge produced." Essentially, they postulate that "it is precisely the intention of knowledge economy and innovation policies to reshape the terms of universities and academics' future engagement with the economy and also society and culture" (Kenway et al., 2004).

The major critique to the innovation policies has been how universities have been implicated in a technologically deterministic logic. In other words, the theorizing literature on same argues that "they accord technology undue power as an agent of change, especially of the particular knowledge that is produced and taught in universities and the knowledge that languish as a result". Again, Kenway et al. (2004) report that the innovation policy has been criticized because it tends to assume a 'developmental trajectory' and therefore tends to stress the independence of technology from social forces and focus instead on the logical development of one innovation to the next (Kenway et. al, 2004). These thoughts have been further elucidated by Bimba (1995) that there is an assumption that "technological developments occur according to some naturally given logic, which is not culturally or socially determined and that these developments force social adaptation and changes". According to Kenway et al. (2004), these are positioned as forces over which people have no control, thus inviting passive accommodation of technologically induced change (Kenway et. al, 2004). An earlier study of Elam (1994) argued that "as a critical stage of advancement is reached, it becomes very difficult for national economies and individual firms to opt-out of the new technological regime; they become 'locked-in' to a universal development trajectory." 
As reported by Kenway (2009), "the competitive environment associated with innovation policy has the effect of denying tradition, compressing time and producing a sense of urgency with some already recognized unfortunate side effects." Also in relation to these thoughts on innovation policy and techno-preneur debates, Pearson (2004) has noted examples of intellectual theft, cutting corners and a reluctance to engage in the informal and free exchange of ideas (Pearson, 2004). The theorizing literature has argued that "taken to its extreme, research driven by innovative systems may discourage honesty, reflexivity and intellectual selflessness" (Kenway et al., 2004).

\subsubsection{Transmission of Educational Policies into Practice}

Significantly, teachers are the fulcrum of any educational system by virtue of the fact that they transmit educational policies into practice and action (Asiyai, 2013). To this end, one of the fundamental roles of every teacher is to transmit knowledge into his/her students by helping them to learn and grow in the area that the teacher's course focuses on (Clark and Cutler, 1990). Lecturers also set the pace for their students by helping them to learn effectively through devising learning experiences that pertain to students' interest (Asiyai, 2015). Here, we can talk of the teacher as a facilitator.

\subsubsection{Teacher as a Facilitator of Learning}

As we continue to live in a society where people aspire to change and as nations aspire to develop, the basic roles of teachers have as well been shaped to include the facilitation of the change(s) that people so desire through interaction with students. This tells us the extent to which the demands of a university teacher are directly linked with the world's transition as well as reforms in tertiary education. Today, the teacher is obliged to provide an environment that seeks to promote critical thinking and problem solving skills unlike it was in the past where the teacher only taught his ideas alone (Heck and Williams, 1984).

In an earlier study by Heck and Williams (1984), they placed a distinction between "how to think" and "what to think." They argued among other things that with an avowed interest in critical thinking, teachers now insist on designing their courses to show their students "how to" rather than "what to" think. This as reported in the literature motivates and intellectually stimulates the student to indulge in critical thinking through the process of reading and experiencing (Heck and Williams, 1984). Again, in an earlier study by Armstrong and Savage (1983), they postulated that successful teachers are those that recognize and work towards the need to teach students to apply, analyze, synthesize and evaluate what they have learnt. It is believed that one way of demonstrating the "facilitator of learning" role is by questioning and examining the students. This act supports the development of students as they go through the search and enquiry process (Armstrong and Savage, 1983).

\subsubsection{Teacher as an Administrator}

Asiyai (2015) likened the role of the university teacher in promoting quality education to that of a manager charged with the provision of stimulative and conducive learning environment to enable students' productive learning and effective classroom management. Similarly, teachers indulge in activities that are somewhat equivalent to the administrator of any given firm. They keep records of attendance, mark and grade students and as well plan and organize the classroom for effective teaching (Heck and William, 1984). Aside these, other tasks that are undertaken by teachers and are common to administrators include scheduling, communicating, reporting and evaluating (Heck and William, 1984). Heck and Williams (1984) have argued that the reporting and evaluation of the progress of students mostly ushers them (teachers) into being researchers. As teachers monitor students and evaluate students' efforts, they are required to keep meticulous records of students' 
assignments, reports, attendance and test scores (Clark and Cutler, 1990).

As highlighted by Semradova and Hubackova (2014) the "activities of university teachers are characterised with professional competencies in the fields of their specialisation and research, in the areas of teaching and management." When it comes to the competencies of the lecturer, Semradova and Hubackova (2014) expressed it in terms of accepting a responsibility and a call to responsibility. Explaining further, they added that "responsibility and competence complement and enrich each other" taking into consideration the "gnoseo-logical, methodological, axiological and ethic levels." Closely related to the assertion by Semradova and Hubackova (2014) is the argument put forward by Kratochvil (1995). He echoes that, "education is not based on a method but on responsibility." He continued by stating that it would be irresponsible, however, "not to rely on a method at least in the situations in which we have no insight and that education should lead to responsibility instead of being a process of giving instructions on how to use manuals." In essence, although education, according to Kratochvil (1995), is based on responsibility, it is imperative for providers of education including university teachers to rely on a method in instances where they do not understand the true nature of a situation in order to achieve the set goals of education.

\subsubsection{Teacher as an Understander and a Nurturer}

To adequately impart knowledge into students, one other important role assumed by teachers is understanding. By understanding, teachers are required to know the individual differences, strengths as well as weaknesses of students. This draws our attention to the nurturing role of the university teacher. Clark and Cutler (1990) are of the view that, when a teacher is able to accommodate individual differences among his or her students, it leads partly to the appreciation of certain conducts of the students. In this respect, teachers are able to understand the behavior, actions as well as inactions of their students. Being able to play this role well (understanding your students) brings about greater effectiveness on the part of teachers (Clark and Cutler, 1990). In order to function well as a teacher, one has to comprehend, accept, value, affirm and have respect for all people irrespective of the differences in sex, race, culture and religious affiliations. Teachers observe their students to ascertain awareness of their personalities (Clark and Cutler, 1990). It is believed that understanding the learner in the course of nurturing him/her helps to develop the skills and attitudes needed for teaching in an environment with miscellaneous people. To properly understand and nurture students, teachers are entreated to view each of them as unique entities (Heck and Williams, 1984). Teachers therefore fail to gain deeper insight and miss the opportunity to understanding their students when they overlook the various differences that characterize them. A research conducted by Nabaho et al. (2017) at the Makerere University in Uganda revealed that students regard good teachers as those that are student-centred, demonstrate strong subject knowledge, approachable, responsive, organized and are able to communicate well (Nabaho et al., 2017).

\subsubsection{Teacher as a Socializer}

Closely related to nurturing is the socializing role played by teachers. The school and the teacher in particular are tasked with the obligation of completing the socialization process. They help to nurture the students from the point their families pause and enroll them in schools (Friesen and Boberg, 1990). The socializing role involves the process by which teachers learn new behaviors, unlearn old ones, adjust or adapt to the teaching environment in order to meet the expectation of the school and the set-goals to be accomplished. In this respect, they are required by duty to fraternize with the culture of their school, its rules, policies, and the regular course of doing things (Clark and Cutler, 1990). Teachers also help their students to channel their concerns by creating better rapport between themselves and the students. Teachers are required by their profession to support the activities of teaching and learning by opening their doors and creating more room for their students to be able to express their views on both class and other non-curricular activities. This role played by teachers 
ensure the delivery of quality services to their students and the school at large. Clark and Cutler (1990) have argued that building "bread-and-butter" relationship with your students bridges the communication gaps and ensures the accomplishment of the goals of teaching as well as the expectation of students. Simply put, productive relationship increases students' learning. Through their interaction with their students, teachers portray a positive image for their students. They tend to be role models to their students as their way of life is always observed and sometimes imitated by some students (Green, 1971). Put differently, teachers provide learning experiences which are adopted by their students pertaining to their needs and abilities (Friesen and Boberg, 1990). They instill values, customs, and certain beliefs into the students on one hand and develop individual students based on classroom experience on the other hand (Friesen and Boberg, 1990; Ornstein, 1995).

Teachers assist students to recognize their particular values, consider the consequences of those values and be wary of how those values may conflict with each other's values (Ornstein, 1995). They shape behaviors of their students by motivating, encouraging and disciplining them (Green, 1971). The ultimate roles played by teachers are the shaping of beliefs and the transmission of knowledge (Green, 1971). So, the role of the university lecturer in a microcosm within a wider macrocosm supports students to take appropriate steps/responsibilities for their successes (Ornstein, 1995).

\subsubsection{Maintenance of Classroom Control}

Achieving and maintaining classroom control tends to be one of the major roles played by teachers. This is attributable to the fact that being able to control the class is very paramount to establishing a healthy relationship with students (Clark and Cutler, 1990; Ornstein, 1995). However, increasing students' population has undermined the possibility of maintaining class control simply because the numbers outweigh the capacity of lecture theatres. The challenges associated with the emergence of large class size include; increase in workload of faculty members, negative feedback in terms of output from students, informal exchanges between students, reduction in the level of participation and limited meaningful interaction with lecturers (Clark and Cutler, 1990; Mwiria et al., 2007 and Mulryan-Kyne, 2010). All these can erode the purpose of achieving quality in educating students. In line with this, Mwiria et al. (2007) have hinted that lecturers in the Kenyatta University in the 1990s had to repeat the same lectures to as many as three to four groups of students because of inadequate lecture theatres. In other cases, some students had to listen to the lectures through windows. Similarly, at Moi University in Kenya, about 1,80o students in one class had to take their notes from outside the lecture hall through a public address system (Mwiria et al., 2007). Comparatively, the situation in Ghanaian public universities is not different from that of the Kenyan experience where in a limited faculty, a lecturer could handle about eight courses. Besides this, there is the question of academic staff and student ratio.

According to the National Council for Tertiary Education (NCTE) report of 2004, staffing norms for the universities require an academic staff and student ratio of 1:12 for science; 1:8 for medicine; 1:18 for humanities and 1:15 for education (Manuh et al., 2007). In 2012, the NCTE revised the staffing norms to reflect the realities in the tertiary education sector. Consequently, the staffing norms for universities require an academic staff and student ratio of 1: 27 for Social Sciences and Humanities; 1:27 for Business Administration; 1:18 for Science; 1:18 for Applied Science, Technology and Health Science; 1:18 for Engineering; 1:15 for Pharmacy and 1:12 for Medicine (NCTE, 2012). It is imperative to note that the NCTE's national norms stipulate an overall institutional students/staff ratio of 15:1 (Manuh et al., 2007). The staffing norms for the universities are summarized in table 1 whereas tables 2 and 3 present the students/academic staff ratio in public universities for 2014 by subject categories and basic statistics for public universities in the 2016/17 academic year respectively. 
Table 1: Staffing Norms for Universities: Academic Staff and Student Ratio

\begin{tabular}{|l|c|c|}
\hline SUBJECT CATEGORY & $\mathbf{2 0 0 4}$ & 2012 (REVISED) \\
\hline Social Sciences and Humanities & $1: 18$ & $1: 27$ \\
\hline Business Administration & - & $1: 27$ \\
\hline Science & $1: 12$ & $1: 18$ \\
\hline Applied Science, Technology and Health Sci. & - & $1: 18$ \\
\hline Engineering & - & $1: 18$ \\
\hline Pharmacy & - & $1: 15$ \\
\hline Medicine & $1: 8$ & $1: 12$ \\
\hline Education & $1: 15$ & - \\
\hline
\end{tabular}

Source: Manuh et al. (2007) \& NCTE, Norms for Tertiary Education (Universities), 2012

Table 2: Student Academic Staff Ratio in Public Universities, 2014

\begin{tabular}{|l|c|c|}
\hline CATEGORY & NORM & ACTUAL \\
\hline HUMANITIES & $27: 1$ & $50: 1$ \\
\hline BUSINESS ADMINISTRATION & $27: 1$ & $120: 1$ \\
\hline SCIENCE & $18: 1$ & $32: 1$ \\
\hline APPLIED/ TECH AND HEALTH SCIENCE & $18: 1$ & $37: 1$ \\
\hline ENGINEERING & $18: 1$ & $44: 1$ \\
\hline PHARMACY & $15: 1$ & $25: 1$ \\
\hline MEDICINE & $12: 1$ & $16: 1$ \\
\hline
\end{tabular}

Source: NCTE Annual Report, 2014

Table 3: Basic Statistics on Public Universities for 2016/2017 Academic Year

\begin{tabular}{|c|c|c|}
\hline STUDENT ENROLMENT & FULL-TIME TEACHING STAFF & STUDENTS/ STAFF RATIO \\
\hline \multicolumn{3}{|c|}{ GENERAL } \\
\hline 167,736 & 4,084 & 41:1 \\
\hline \multicolumn{3}{|c|}{ UNIVERSITY OF GHANA } \\
\hline 36,739 & 1,033 & $36: 1$ \\
\hline \multicolumn{3}{|c|}{ KWAME NKRUMAH UNIVERSITY OF SCIENCE AND TECHNOLOGY } \\
\hline 36,930 & 804 & $46: 1$ \\
\hline \multicolumn{3}{|c|}{ UNIVERSITY OF CAPE COAST } \\
\hline 20,495 & 696 & 29:1 \\
\hline \multicolumn{3}{|c|}{ UNIVERSITY OF DEVELOPMENT STUDIES } \\
\hline 18,749 & 474 & 40:1 \\
\hline \multicolumn{3}{|c|}{ UNIVERSITY OF EDUCATION, WINNEBA } \\
\hline 34,763 & 449 & 77:1 \\
\hline \multicolumn{3}{|c|}{ UNIVERSITY OF MINES AND TECHNOLOGY } \\
\hline 2,248 & 109 & 21:1 \\
\hline \multicolumn{3}{|c|}{ UNIVERSITY OF ENERGY AND NATURAL RESOURCES } \\
\hline 3,029 & 93 & 33:1 \\
\hline \multicolumn{3}{|c|}{ UNIVERSITY FOR HEALTH AND ALLIED SCIENCES } \\
\hline 2,694 & 200 & 13:1 \\
\hline \multicolumn{3}{|c|}{ UNIVERSITY OF PROFESSIONAL STUDIES, ACCRA } \\
\hline 12,089 & 226 & 53:1 \\
\hline
\end{tabular}

Source: NCTE, Summary of Basic Statistics on Public Universities 2016/2017 
From tables 2 and 3 above, it is evident that the academic staff and student ratio in the public universities defies the staffing norms stipulated by the NCTE. This affirms the position of Manuh, Gariba and Budu (2007) that the existing proportion of students to a faculty varies widely from the NCTE's standard norms. In addition, it appears that this proportion has experienced a persistent increase over the years but varies across institutions. While some institutions experience extreme students to staff ratios, others experience mild ratios as seen in the proportions of University of Cape Coast, University of Mines and Technology and the University for Health and Allied Sciences. In the Kwame Nkrumah University of Science and Technology (KNUST) for instance, the institution experienced an extreme proportion between 2016/17 academic year and 2018/19 academic year. In 2016/17 academic year, the institutional ratio of students to an academic staff was 46 students to an academic staff as evidenced in table 3. In 2018/19 academic year, the ratio stood at 59 students to an academic staff with students' population (undergraduate, graduate and distance) of 56, 139 and full time teaching staff of 956 (KNUST Facts and Figures 2018/19, 2019).

Significantly, the students/staff ratio is directly linked with the challenges that undermine quality university education specifically to the emergence of large class sizes. The large class size in turn compounds lecturers' difficulty as they face the problems of increased workload, negative feedback in terms of output from students, informal exchanges between students, reduction in the level of participation and limited meaningful interaction with lecturers (Clark and Cutler, 1990; Mwiria et al., 2007 and Mulryan-Kyne, 2010).

Increasing student enrolment over the years has undoubtedly culminated into pressure on facilities such as libraries, lecture theatres, laboratories and residential accommodation. This is obvious in our public universities. How will things look like in the foreseeable future as Ghanaian universities anticipate quantum increase in enrollment with the completion of the first beneficiaries of the free SHS policy in 2020 ? In a situation such as this, university teachers have to be receptive to the changing times and resort to useful and more efficient techniques of teaching. They must take advantage of all available and possible Information and Communication Technology (ICT) tools which are useful for studying, teaching and even for mutual encounters. This notwithstanding, lecturers can adopt the mechanism of co-teaching and the division of large classes into smaller sections. To this end, they can also take advantage of Graduate Research Fellows, Graduate Teaching Assistants and Demonstrators in the process of teaching and learning.

However, if free Senior High School education means increasing enrolment at the university level, it is incumbent upon us to pay critical attention to some factors that have the tendency to influence the processes of teaching and learning. As reported in the Education for All (EFA) Monitoring Report of 2005, the factors that affect the processes of teaching and learning are learner characteristics, context, inputs as well as outcomes (Barrett et al., 2006). The learners' characteristics are concerned with previous learning experience, health, culture and religion as well as place of residence. The context encapsulates the various societal values and attitudes as well as national policies. Again, inputs on its part represents the material and human resources available to impart essential and productive knowledge to the students. You would appreciate the fact that of all these factors, accommodation appears to be the most threatening to the delivery of quality education in various universities. It appears that every year, the intake of students in tertiary institutions increases with accommodation issues still posing a threat (Adu-Gyamfi et al., 2014; Chiguvi and Ndoma, 2018). Writing on the issue of accommodation using the Kwame Nkrumah University of Science and Technology as a focal study, Adu-Gyamfi et al., (2014) revealed that inadequate accommodation within walking distance has compelled students to sleep in unacceptable places like study rooms, common rooms and television rooms especially during examinations. In fact, the increase in enrolment does not correlate with the existing accommodation. The challenge with accommodation is so serious to the extent that students reside anywhere including the phenomenon of "squatting or perching" - a practice where non-resident students illegally reside with official tenants of the hall under unofficial arrangements. We emphasize, that the wellbeing of students are largely influenced by the quality of their housing, which in turn has an impact on their performance (Ameyaw et al., 
2016). This issue of accommodation has the tendency of rendering psychological challenges on students and hence, impacts negatively on the learner's characteristics to the extent of militating against the efforts or inputs made by teachers. Manuh et al., (2007) have added that the issue of accommodation is a serious threat to the welfare of university students and this negates the quest for quality despite the efforts of teachers.

The quality of university education is not only contingent on the university teacher, variables like gender-attitudes, socio-economic status, the number of teachers or faculties in a particular programme or departments, can influence the level of quality that can be derived from university education in Ghana. Asiyai (2013) has argued, among other things that quality in university education is dependent on the quality and quantity of human and material resources put in place in institutions of higher learning (Asiyai, 2013). The President's Committee on the Review of Education Reforms in Ghana in 2002 noted with concern that "inadequate funding and lack of modern facilities for research, the growing teaching load on faculty due to an increasing number of students, lack of clearly articulated research priorities at the national and institutional levels, absence of strong academic and research leadership and inadequate number of well-motivated staff at the professional level, have all hampered the process of knowledge production at the public universities" (Manuh et al., 2007).

It is argued that financial pressure on teachers to find other sources of remuneration militates against their capacity to act as agents of change in the rapidly reforming Ghanaian state (Osei, 2006). Benell and Acheampong (2007) have protested that teachers in many countries in Sub-Saharan Africa are being asked to change radically teaching practices at a time when the majority of them are increasingly de-motivated (Benell and Acheampong, 2007). In contrast, a study by Manuh et al. (2007) reveals that satisfactory remuneration levels alone might not be enough for universities to attract and retain staff (Manuh et. al., 2007). At the university level, we need to pay attention to other important elements/theories concerning motivation. These include; intrinsic and extrinsic motivation. In order to achieve intrinsic motivation, the university teacher must experience interest and enjoyment in his or her task. It should also go along with feeling of competency and selfdetermination (Deci and Ryan, 1985). A university teacher with high achievement motivation will explore his or her environment, take the necessary and calculated risk and look for concrete strategies for progress (Deci and Ryan, 1985). This must be in tandem with the level of confidence of students lecturers teach and mentor. In fact, a study done by Sikhwari (2007) at the University of Venda in South Africa suggests that confidence and positive self-concept impact on students' motivation to achieve (Sikhwari, 2007). Therefore, in achieving higher standards and for that matter quality in University education, there should also be highly motivated students who try to achieve academic success through attending classes regularly and participating in class discussions (Sikhwari, 2007). These have the tendency or proclivity to ensure that they perform well in examination and also master the required skills that are demanded by industries.

While attention is drawn to these weightier matters, the role of libraries in ensuring quality in universities in the areas of teaching, learning and connecting to other scholarly communities is a major concern (Manuh et al., 2007). Therefore, it is permissible to state that libraries in our universities exist to support the efforts of university teachers to attain and maintain high quality academic standards. Meanwhile, university libraries in Ghana are confronted with the challenge of providing adequate spaces to accommodate the growing number of students among other challenges (Manuh et al., 2007).

\section{Conclusion}

Education is sacred, and should not be experimented; hence policies and strategies to make it work should not travel on the back of political expediency. Policies arising thereby should go through the crucible of what is useful but not mundane. It must pass the litmus test of delivering quality education. If free Senior High School education means increasing enrolment at the university level, 
there must be rapid recruitment of cutting edged scholars (faculty members) as soon as possible. It is expedient to lift the cap/ban on hiring in perpetuity. In fact, the number of faculty members within the current arrangement cannot deliver the quality we envisage. Major stakeholders of education have proposed increasing infrastructure and educational facilities in our universities to contain the expected enrolment in the near future to enable them achieve quality university education. This could be true when reference is made to other countries like Sri Lanka where the quality of education in public schools is hinted to be low as more schools lack infrastructural and educational facilities under free secondary education (Asankha, 2011; Gamlath, 2013). Stakeholders cannot overlook other weightier matters.

There is the need to improve the conditions prevailing at the Senior High Schools through the provision of required infrastructure, teaching aids and well-equipped laboratories as well as acceptable teacher motivation to give the SHS students smooth and worthwhile transition. It is important to emphasize that any deficit in the training of students at this level can affect the expected quality of students who transit into the universities. As Ghana anticipates a large number of secondary school force in the public universities, they can use a form of critical academic selection process to select the best to enter the universities. It is therefore essential to have a discussion on the assertion that "university education is not for all." All are not required (supposed) to be in the university.

It is expedient to argue that quantity and quality must run pari passu. On this note, the authors concur with Akinpelu (2000) that education with no quality can even be more dangerous than no education, hence without quality, education is meaningless and has no value (Akinpelu, 200o). The implementation of successive educational policies such as the free SHS policy should necessitate the creation of new and innovative coping mechanisms by universities to reflect the change in environment. Yet at the heart of these issues is the teacher who serves as the fulcrum or pivot around whom the attainment of quality education revolves. At the time of the publication of this piece, the government of Ghana had lifted the ban on recruitment of lecturers and supporting staff. It is anticipated that a university workforce, "six thousand strong," (Afful, 2017) shall join the existing faculties as administrators under the public universities of Ghana. When this is achieved, it shall reduce the burden on lecturers and supporting staff. After all, the quality agenda shall not lose steam amidst the growing challenges in education.

\section{References}

Abdul-Rahaman, Nurudeen et al. (2018). “The Free Senior High Policy: An Appropriate Replacement to the Progressive Free Senior High Policy.” International Journal of Education and Literacy Studies 6.2

Adu-Gyamfi Samuel, Brenya Edward and Lamptey E.L Eileen, (2014). "Accommodation Reforms and Its Effects on Students: A focus on Kwame Nkrumah University of Science and Technology from 1960 to 2013." Global Journal of Human-Social Science Vol. 14(2). Pp. 53-8o.

Adu-Gyamfi Samuel, Donkoh W J and Addo A A. (2016) “Educational Reforms in Ghana: Past and Present." Journal of Education and Human Development Vol. 5(3). Pp. 158-172.

Afful, Benson. (November 09, 2017). "Ban on education recruitment lifted!...22,802 personnel cleared." BEFT Online. Available at: https://thebftonline.com/2017/business/ban-on-education-recruitment-lifted22802personnel-cleared/

Akyeampong, Kwame, (2009). "Revisiting Free Compulsory Universal Basic Education (FCUBE) in Ghana." Comparative Education Vol. 45(2). Pp. 175-195.

Ameyaw, Stephen, Elvis Attakora-Amaniampong And Kofi Osei, (2016). "Evaluation of Students' Housing Facilities: Lessons for Enhancing the Design and Construction of Higher Educational Built Infrastructure." Ghana Journal of Higher Education Vol. 3

Armstrong G. David and Savage V. Tom, (1983). Secondary Education: An Introduction. New York: Macmillan Publishing Co., Inc.

Asankha Pallegedara and Takashi Yamano, (2011). "Impact of Universal Secondary Education Policy on Secondary School Enrollments in Uganda.” Journal of Accounting, Finance and Economics Vol. 1 (1). Pp. 16-30. 
Asiyai Ifeoma Romina, (2015). "Improving Quality Higher Education in Nigeria: The Roles of Stakeholders". International Journal of Higher Education Vol.4 (1). Pp. 61-70.

Barrett et al, (2006). "The Concept of Quality in Education: A Review of the 'International' Literature on the Concept of Quality in Education." EdQual Working Paper 3.

Billy Wong and Yuan-Li Tiffany Chiu, (2017). "Let me entertain you: the ambivalent role of university lecturers as educators and performers." Educational Review.

Botswana Educational System: Overview. Available at https://education.stateuniversity.com/pages/186/BotswanaEDUCATIONAL-SYSTEM-OVERVIEW.html (Accessed on 9th September, 2019).

Chiguvi Douglas and Ndoma T Jairus, (2018). "The effects of shortage of accommodation on students' performance in private tertiary institutions in Botswana." Journal of Economics and Sustainable Development Vol. 9 (4). Pp.97-104.

Chimombo P.G. James, (2005). "Quantity versus Quality in Education: Case Studies in Malawi." International Review of Education Vol. 51 (2/3). Pp. 155-172.

Clark Cercil D. and Cutler R. Beverly, (1990). Teacher: An Introduction. Brigham: Harcourt Brace Jovanovich.

Constitution of the Republic of Ghana. Government of Ghana. <http://www.ghana.gov.gh/images/documents /constitution_ghana.pdfs (Accessed on 9th September, 2019).

Education Sector Performance Report, August 2013. Available at www.moe.gov.gh/assets/media/docs /FinalEducationSectorReport-2013.pdf. (Accessed on 9th September, 2016)

Francisca Kakra Forson, (2017). "Ghana Launches Free High School Education”. Voanews.com (15 September, 2017) Available at https://www.voanews.com/africa/ghana-launches-free-high-school-education (Accessed on 15 September, 2017)

Friesen W. John and Boberg L. Alice, (1990). Introduction to Teaching: A Socio-Cultural Approach. USA: Kendall/ Hunt Publishing Company.

Green F. Thomas, (1971). The Activities of Teaching. USA: McGraw-Hill Inc.

Heck F. Shirley and Williams R C, (1984). The Complex Roles of the Teacher: An Ecological Perspective. New York: Teachers College Press.

Jane Kenway, Elizabeth Bullen and Simon Robb, (2004). "The Knowledge Economy, The Techno-Preneur and the Problematic Future of the University." Policy Fortunes in Education Vol. 2 (2). Pp.330-349

Kwame Nkrumah University of Science and Technology (KNUST), (2019). Facts and Figures 2018/19.

Lloyd CB, Gage-Brandon AJ, (1992). Does Sibsize Matter? Implications of Family size in Children's Education in Ghana. Presented at the Annual Meeting of the Population Association of America, Denver, Colorado, April 30 - May 2, 1992. Princeton University Library (SPR). Available at http://www.popline.org/node/

Louise Morley, Fiona Leach, Rosemary Lugg, (2009). "Democratising Higher Education in Ghana and Tanzania: Opportunity Structures and Social Inequalities". International Journal of Educational Development Vol. 29 (1). Pp. 56-64.

Majasan James, (1998). Qualitative education and development. Ibadan: Spectum Books Limited.

Manuh, Takyiwaa, Sulley Gariba and Joseph Budu, (2007). Change and Transformation in Ghana's Publicly Funded Universities: A Study of Experiences, Lessons and Opportunities. Accra: Woeli Publishing Services.

Ministry of Education (MoE) (n.d), Ghana. Education Sector Analysis 2018. Accra: MoE,

Ministry of Education (MoE) (n.d), Ghana. Education Sector Performance Report, 2015. Accra: MoE.

Mulryan-Kyne Catherine, (2010). "Teaching large classes at college and university level: challenges and opportunities". Journal of Teaching in Higher Education Vol. 15(2). Pp. 175-185

Mustapha Hameed, (2017). "A Moral Case for Free Senior High School Education (Free SHS)". Modernghana.com. Available at https://www.modernghana.com/news/818691/a-moral-case-for-free-senior-high-schooleducation.html (Accessed on 9th September, 2019)

Mwiria, Kilemi et al (2007). Public and Private Universities in Kenya: New Challenges, Issues and Achievements. Nairobi: East African Educational Publishers.

Nabaho Lazarus et al (2017). "Good Teaching: Aligning Student and Administrator Perceptions and Expectations". Higher Learning Research Communications Vol. 7 (1).

National Council for Tertiary Education (NCTE), (2012). Ghana. Norms for Tertiary Education (Universities). Accra: NCTE.

National Council for Tertiary Education (NCTE), (n.d). Ghana. Annual Report, 2014. Accra: NCTE.

National Council for Tertiary Education (NCTE), (n.d). Ghana. Summary of Basic Statistics on Public Universities 2016/2017. Accra: NCTC.

Nwachukwu Prince Ololube et al (2013). "Education for Development: Impediments to the Globalization of Higher Education in Nigeria." International Journal of Education Foundation and Management Vol. 1 (2). Pp. 109-130

Ornstein C. Allan. Strategies for Effective Teaching. Wm. C. Brown Communication, Inc.. 
Osei M. George, (1995). “Teachers in Ghana: Issues of Training, Remuneration and Effectiveness”. International Journal of Educational Development Vol. 26 (1) (January 2006). Pp. 38-51.

Schindler Laura et al, (2015). "Definitions of Quality in Higher Education: A Synthesis of the Literature.” Higher Learning Research Communications Vol. 5 (3). Pp. 3-13.

Semradovaa Ilona and Sarka Hubackova, (2014). "Responsibilities and Competences of a University Teacher." Social and Behavioral Sciences Vol. 159. Pp. $437-441$

Sharmila Gamlath, (2013). ““Freeing” Free Education in Sri Lanka.” Asian Education and Development Studies Vol. 2 (1). Pp. 33-52

World Conference of Higher Education (1998). "Higher Education in the Twenty-first Century: Vision and Action" UNESCO-Paris. 